Environmental Research Journal 5 (3): 121-130, 2011

ISSN: 1994-5396

(C) Medwell Journals, 2011

\title{
Seasonal Variation of Heavy Metals Accumulation in Water and Oyster (Saccostrea cucullata) Inhabiting Central and Western Sector of Indian Sundarbans
}

\author{
${ }^{1}$ Prabal Barua, ${ }^{2} \mathrm{Abhijit} \mathrm{Mitra,}{ }^{2}$ Kakoli Banerjee and ${ }^{3} \mathrm{M}$. Shah Nawaz Chowdhury \\ ${ }^{1}$ Fisheries and Aquaculture Division, Department of Zoology, \\ University of Calcutta, 35. B.C. Road, Kolkata 700019, West Bengal, India \\ ${ }^{2}$ Department of Marine Science, University of Calcutta, 35. B.C. Road, \\ Kolkata 700019, West Bengal, India \\ ${ }^{3}$ Institute of Marine Sciences and Fisheries, University of Chittagong, \\ Chittagong 4331, Chittagong, Bangladesh
}

\begin{abstract}
Most estuaries receive high heavy-metal input from industries. This is reflected in the relatively high levels found in estuarine organisms. Seafood containing heavy metals as a result of environmental contamination causes toxicity in human beings. To evaluate such kind of contamination, this study targeted the analysis of selected metals in estuarine water and oyster (Saccostrea cucullata) collected from Indian Sundarbans. The heavy metals in tissue samples were estimated using a Perkin-Elmer Sciex ELAN 5000 ICP mass spectrometer. Significant variation of heavy metals in water and oyster tissues collected from four different sampling stations ( 2 each in central and western sector) of Indian Sundarbans were observed. The distribution of heavy metals in ambient water and Saccostrea cucullata followed the order $\mathrm{Fe}>\mathrm{Mn}>\mathrm{Zn}>\mathrm{Cu}>\mathrm{Pb}>\mathrm{Ni}>\mathrm{Co}>\mathrm{Cd}$ and $\mathrm{Zn}>\mathrm{Fe}>\mathrm{Cu}>\mathrm{Mn}>\mathrm{Pb}>\mathrm{Co}>\mathrm{Ni}>\mathrm{Cd}$, respectively. Heavy metal concentration in the water and oyster tissues tended to vary significantly among season and monsoon period showed particularly high metal concentration compared to pre-monsoon and post-monsoon. However, due to urbanization and unplanned tourism, a negative impact has been exerted on the positive health of the aquatic system. The contamination of water is also transmitted in the biological compartment, many of which are consumed as food by the local people. The low salinity and intense industrialization in the Hooghly estuarine stretch may be attributed to high concentration of heavy metals in the oyster muscle inhabiting the western sector than Central sector of Indian Sundarbans.
\end{abstract}

Key words: Trace metals, Saccostrea cucullata, Indian Sundarbans, Hooghly estuary, monsoon, industrialization, urbanization, low salinity

\section{INTRODUCTION}

Heavy metal concentration in aquatic environment is critical concern, due to toxicity of metal and their accumulation in aquatic habitats. A large part of the heavy metal input ultimately accumulates in the estuarine zone and continental shelf, since these areas are important sinks for suspended marine and associated land-derived contaminants. Heavy metals introduced into the aquatic environment by dumping domestic and municipal wastes, industrial effluents, urban run off, agricultural run-off, atmospheric deposition and mining activities (Srinivasa et al., 2007).

Marine organisms accumulate and concentrate heavy metals to high levels. Consequently, they are widely used as biomonitors indicating the extent of metal pollution in coastal waters (Lacerda et al., 1985; Raposo et al., 2009). Marine molluscan acts as indicators of contamination levels which are widely used in international and national Mussel Watch Program. Marine bivalves such as oysters have shown to have many advantages as bio-indicators for monitoring trace substances in coastal waters because of their wide geographical distribution, sessile life style, easy sampling and tolerance of a considerable range of salinity, resistance and high accumulation of a wide range of chemicals. Dense populations and communities of marine bivalves are commonly found in tidal environments where water flow provides an energy subsidy to these sessile animals by transporting in food and taking away wastes and inorganic materials. In these systems, bivalves are closely coupled to the water column and heavily dependent on the exchange of water

Corresponding Author: Prabal Barua, Sohani Tower, 446/D-33, Muhammadpur Residential Area, Muradpur, Chittagong 4212, Chittagong, Bangladesh 
(Takeoka et al., 1991; Goldberg et al., 1978). The ability of bivalve to accumulate heavy metals in their bodies to elevated levels reaching concentrations that are much higher than those of ambient water concentrations makes these organisms useful for assessment purposes (Turkmen et al., 2005). However, there is no consensus whether transplanted bivalves can accumulate trace elements up to the values found in resident populations and how much time is necessary for them to reach environmentally representative concentrations. Oysters have been identified as good bioindicators of pollution in aquatic environments in worldwide coastal areas (Jaffe et al., 1999).

The oyster is a scientifically the best known marine animal in the world. Oysters have proved highly amenable to aquaculture and exploitation of wild populations that contributes little to worldwide oyster production $(\mathrm{FAO}, 2002)$. Oysters have been introduced worldwide to almost 73 countries, considered as ecosystem engineers are influencing many ecological processes that preserves biodiversity, population and food web dynamics and nutrient cycling. The oyster-bed is an example of biocoenosis or a social community of living beings (Jacqueline et al., 2009).

The present study was conducted in the Indian Sundarbans which is a large mangrove ecosystem in the north-east coast of India located at the apex of the Bay of Bengal (between $21^{\circ} 40 / \mathrm{N}-22^{\circ} 40 / \mathrm{N}$ latitude and $88^{\circ} 03 / \mathrm{E}$ to $89^{\circ} 07 / \mathrm{E}$ longitude). The presence of 34 true mangrove species and some 62 mangrove associate species (Mitra, 2000 ) in the zone is the only mangrove based home ground of Royal Bengal tiger (Panthera tigris) in the planet. The deltaic complex sustains 102 islands, out of which 48 are inhabited and 54 are uninhabited. The flow of Ganges (Bhagirathi) river through Hooghly estuary in the western sector of Indian Sundarbans to end up at Bay of Bengal has made the geographical situation totally different from the central sector where five major rivers have lost their root with Ganga-Bhagirathi system due to heavy siltation. The main sources of heavy metals in the Indian Sundarbans are the industries, fishing harbour, agricultural activity, Haldia seaport, urbanized wastes on the western sector of Indian Sundarbans along the bank of Hooghly estuaries (Mitra, 1998) (Table 1).

The most widely distributed species of oyster in Indian Sundarbans is Saccostrea cucullata which is found throughout the Indian ocean and tropical western Pacific (Mitra and Choudhury, 1992). Saccostrea cucullata is the most abundant bivalve in the Hooghly estuary and normally found attached to rocks, boulders and several underwater structures, submerged branches and trunks of mangroves, concrete embankments and piles and even on lighthouse bases of Indian Sundarbans
Table 1: Different sources of heavy metals in Indian Sundarbans (Mitra, 1998)

Trace metals Sources of trace metals in in Indian Sundarbans

Zn Galvanization units, paint manufacturing units and pharmaceutical processes

$\mathrm{Cu}$ Antifouling paints, particular type of algicides used in different aquaculture farms, paint manufacturing units pipe line corrosion and oil sludges (32-120 ppm)

$\mathrm{Pb} \quad$ Discharge of industrial waste waters, such as from painting, dy eing, battery manufacturing units and oil refineries

Mn Wastes from painting industry, pharmaceutical nit and galvanizing industry and other industrial operations

$\mathrm{Ni} \quad$ Untreated wastes from electroplating units, land fill, bubble bursting and gas exchange in ocean, weathering of soils and geological materials, galvanizing and other metal industries

Cd Waste water from electroplating, fossil fuel buming, chemical industries, application of phosphate fertilizers and mining wastes from $\mathrm{Pb}-\mathrm{Zn}$ mines without adequate treatment

Fe Corrosion of pipe lines and pumps, explosive manufacturing units, floating old stranding and rusty barges in the coastal harbours

Co Industrial effluents from metal industry

ecosystem (Mitra et al., 1995). Here we attempted to understand with the 1 year data set the real situation in terms of heavy metal accumulation in edible oyster tissue and ambient aquatic system of Indian Sundarbans. The present paper aims to highlight the level of selective heavy metals ( $\mathrm{Fe}, \mathrm{Zn}, \mathrm{Mn}, \mathrm{Pb}, \mathrm{Cd}, \mathrm{Co}, \mathrm{Cu}$ and $\mathrm{Ni}$ ) in the muscle of Saccostrea cucullata and water body collected from the aquatic subsystem of four stations distributed in two sectors (western and central Indian Sundarbans) of the lower Gangetic region.

\section{MATERIALS AND METHODS}

Study area: Two sampling sites were selected each in the western and central sectors of Indian Sundarbans, a Gangetic delta at the apex of the Bay of Bengal. The deltaic complex has an area of $9630 \mathrm{~km}^{2}$ and houses 102 islands. The western sector of the deltaic lobe receives the snowmelt water of mighty Himalayan glaciers after being regulated through several barrages on the way. It also receives wastes and effluents of complex nature from multifarious industries concentrated mainly in the upstream zone. The central sector on the other hand is fully deprived from such supply due to heavy siltation and clogging of the Bidyadhari channel since the late 15th century (Chaudhuri and Choudhury, 1992). The present geographical locale thus offers a unique test bed to study the effect of pollution on biological species. On this background four sampling stations (two each in western and central sectors) were selected to analyze the concentrations of heavy metals in the water body and Saccostrea cucullata (Table 2 and Fig. 1). 
Table 2: Brief description of experimental area in Indian Sundarbans

\begin{tabular}{|c|c|c|}
\hline Station & Coordinates & Salient features \\
\hline Satjelia island & $88^{\circ} 50^{\prime} 43^{\prime \prime} \mathrm{E}$ & Located in the central sector of Indian \\
\hline (Stn. 1) & $22^{\circ} 11^{\prime} 52^{\prime \prime} \mathrm{N}$ & $\begin{array}{l}\text { Sundarbans. Noted for its wilderness } \\
\text { and mangrove diversity; selected } \\
\text { as the control zone }\end{array}$ \\
\hline Bali island & $88^{\circ} 39^{\prime} 46^{\prime \prime} \mathrm{E}$ & Located in the Matla Riverine stretch in \\
\hline (Stn. 2) & $22^{\circ} 15^{\prime} 45^{\prime \prime} \mathrm{N}$ & the central sector of Indian Sundarbans \\
\hline Chemaguri & $88^{\circ} 09^{\prime} 11^{\prime \prime} \mathrm{E}$ & Located in the western part of Indian \\
\hline$(\operatorname{Stn} .3)$ & $21^{\circ} 39^{\prime} 49^{\prime \prime} \mathrm{N}$ & $\begin{array}{l}\text { Sundarbans and faces river Muriganga } \\
\text { on the eastern side }\end{array}$ \\
\hline Sagar South & $88^{\circ} 01^{\prime} 47^{\prime \prime} \mathrm{E}$ & Situated at the confluence of the River \\
\hline$(\operatorname{Stn} .4)$ & $21^{\circ} 39^{\prime} 04^{\prime \prime} \mathrm{N}$ & $\begin{array}{l}\text { Hooghly and the Bay of Bengal on the } \\
\text { western sector of Indian Sundarbans } \\
\text { This is selected most affected place of } \\
\text { different anthropogenic pollution }\end{array}$ \\
\hline
\end{tabular}

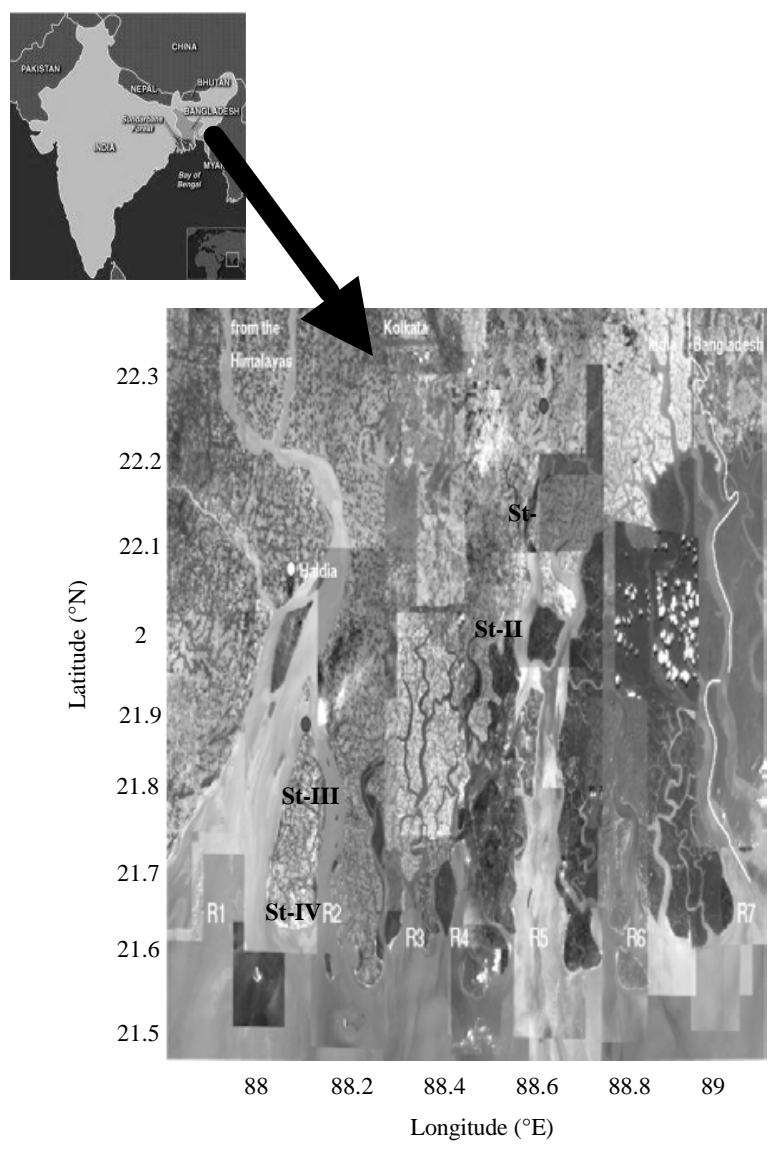

Fig. 1: Map of the study area

Analysis of trace metals in water: Surface water samples were collected using 10-1 Telfon-lined GO-FLO bottles, fitted with Teflon taps and employed on a rosette or on Kevlar line with additional surface sampling carried out by hand. Shortly after collection, samples were filtered through Nucleopre filters $(0.4 \mu \mathrm{m}$ pore diameter) and aliquots of the filters were acidified with sub-boiling distilled nitric acid to a $\mathrm{pH}$ of about 2 and stored in cleaned low density polyethylene bottles. Dissolved
Table 3: Analysis of the reference materials of the near shore sea water (CASS-3)

\begin{tabular}{lllllllll}
\hline Events & $\mathrm{Zn}$ & $\mathrm{Fe}$ & $\mathrm{Pb}$ & $\mathrm{Cu}$ & $\mathrm{Mn}$ & $\mathrm{Ni}$ & $\mathrm{Co}$ & $\mathrm{Cd}$ \\
\hline $\begin{array}{l}\text { Certified } \\
\text { value (ppm) }\end{array}$ & 1.24 & 1.26 & 0.012 & 0.517 & 2.51 & 0.386 & 0.05 & 0.030 \\
$\begin{array}{l}\text { Measured } \\
\text { average (ppm) }\end{array}$ & 1.20 & 1.25 & 0.010 & 0.510 & 2.50 & 0.370 & 0.04 & 0.025 \\
$\begin{array}{l}\text { Maximum (ppm) } \\
\text { Minimum (ppm) }\end{array}$ & 1.30 & 1.50 & 0.020 & 0.525 & 2.70 & 0.390 & 0.08 & 0.035 \\
\hline
\end{tabular}

heavy metals were separated and pre-concentrated from the seawater using dithiocarbamate complexation and subsequent extraction into Freon $\mathrm{TF}$, followed by back extraction into $\mathrm{HNO}_{3}$. Extracts were analyzed for $\mathrm{Zn}, \mathrm{Fe}$, $\mathrm{Cu}, \mathrm{Mn}, \mathrm{Co}, \mathrm{Ni}, \mathrm{Cd}$ and $\mathrm{Pb}$ by A Perkin-Elmer Sciex ELAN 5000 ICP mass spectrometer. The accuracy of the dissolved trace metal determination is indicated by good agreement between the values and reported for certified reference seawater materials (CASS 3) (Table 3 ).

Oyster collection and trace metal analysis: Inductively Coupled Plasma-Mass Spectrometry (ICP-MS) is now a day accepted as a fast, reliable means of multi-elemental analysis for a wide variety of sample types (Date and Gray, 1988). A Perkin-Elmer Sciex ELAN 5000 ICP mass spectrometer was used for the present analysis. A standard torch for this instrument was used with an outer argon gas flow rate of $15 \mathrm{~L} \mathrm{~min}^{-1}$ and an intermediate gas flow of $0.9 \mathrm{~L} \mathrm{~min}^{-1}$. The applied power was $1.0 \mathrm{~kW}$. The ion settings were standard settings recommended, when a conventional nebulizer/spray is used with a liquid

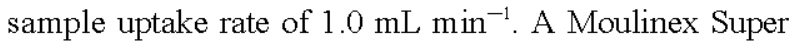
Crousty microwave oven of $2450 \mathrm{MHz}$, frequency magnetron and $1100 \mathrm{~W}$ maximum power polytetrafluoro ethylene (PTFE) reactor of $115 \mathrm{~mL}$ volume, $1 \mathrm{~cm}$ wall thickness with hermetic screw caps were used for the digestion of the muscle samples of the Saccostrea cucullata. All reagents used were of high purity available and of analytical reagent grade. High purity water was obtained with a Barnstead Nanopure II water-purification system. All glasswares were soaked in $10 \%(\mathrm{v} / \mathrm{v})$ nitric acid for $24 \mathrm{~h}$ and washed with deionised water prior to use.

The analyses were carried out on composite samples of 20 specimens of Saccostrea cucullata having uniform size. This is a measure to reduce possible variations in metal concentrations due to size and age. About $20 \mathrm{mg}$ composite muscle samples were weighed and successively treated with $4 \mathrm{~mL}$ aqua regia, $1.5 \mathrm{~mL} \mathrm{HF}$ and $3 \mathrm{~mL} \mathrm{H}_{2} \mathrm{O}_{2}$ in a hermetically sealed PIFE reactor, inside a microwave oven, at power levels between $330-550 \mathrm{~W}$, for $12 \mathrm{~min}$ to obtain a clear solution. The use of microwaveassisted digestion appears to be very relevant for sample dissolution, especially because it is very fast 
Table 4: Concentrations of metals found in standard reference material DORM-2 from the National Research Council, Canada (all data as means \pm standard errors, in $\mathrm{mg} \mathrm{kg}^{-1}$ dry weight)

\begin{tabular}{lrrrrrrrr}
\hline Events & \multicolumn{1}{c}{$\mathrm{Zn}$} & $\mathrm{Fe}$ & \multicolumn{1}{c}{$\mathrm{Pb}$} & $\mathrm{Cu}$ & $\mathrm{Co}$ & $\mathrm{Mn}$ & $\mathrm{Ni}$ & $\mathrm{Cd}$ \\
\hline Certified value (ppm) & 830 & 539 & 0.37 & 66 & 2.25 & 18.50 & 1.04 & 4.15 \\
Measured average (ppm) & 820 & 530 & 0.36 & 64 & 2.20 & 18.45 & 1.02 & 4.10 \\
Recovery (\%) & 99 & 98 & 97.00 & 97 & 98.00 & 99.00 & 98.00 & 98.00 \\
Maximum & 850 & 545 & 0.45 & 68 & 2.35 & 19.50 & 1.08 & 4.20 \\
Minimum & 810 & 525 & 0.30 & 58 & 2.15 & 18.30 & 1.01 & 4.05 \\
\hline
\end{tabular}

(Nadkarni, 1984). After digestion, $4 \mathrm{~mL} \mathrm{H}_{2} \mathrm{BO}_{3}$ was added and kept in a hot water bath for $10 \mathrm{~min}$, diluted with distilled water to make up the volume to $50 \mathrm{~mL}$. Taking distilled water in place of muscle samples and following all the treatment steps described above the blank process was prepared. The final volume was made up to $50 \mathrm{~mL}$. Finally, the samples and process blank solutions were analyzed by ICP-MS. All analyses were done in triplicate and the results were expressed with standard deviation. The accuracy and precision of the results were checked by analyzing standard reference material (SRM, Dorm-2). The results indicated good agreement between the certified and the analytical values (Table 4).

Statistical analysis: A logarithmic transformation was done on the data to improve normality. Analysis of Variance (ANOVA) was performed to assess whether heavy metal concentrations varied significantly between sites, seasons and samples; possibilities $<0.01(\mathrm{p}<0.01)$ were considered statistically significant. Statistical methods applied include correlation analysis $(\mathrm{p}<0.01)$ was done for find out the relationship between dissolved metals and trace metal accumulation of Sacccostrea cucullata.

\section{RESULTS AND DISCUSSION}

The accuracy of the analytical method was checked using two different certified reference materials, mussel tissues (SRM, Dorm-2) and water body (CASS-3) for heavy metal determination. These Certified Reference Materials (CRMs) were considered because no commercial oyster certified material was available at the monitoring study time and the similar matrix effects between water and oyster samples on the trace metal analysis could be assumed. The results (Table 3 and 4) are in good agreement with the certified values. The concentration of $\mathrm{Fe}, \mathrm{Mn}, \mathrm{Zn}, \mathrm{Cu}, \mathrm{Pb}, \mathrm{Ni}$, $\mathrm{Co}$ and $\mathrm{Cd}$ in the water body and Saccostrea cucullata at the sampling stations exhibited a seasonal and station base oscillation. In the present study heavy metals accumulated in water body in the order $\mathrm{Fe}>\mathrm{Mn}>\mathrm{Zn}>\mathrm{Cu}>\mathrm{Pb}>\mathrm{Ni}>\mathrm{Co}>\mathrm{Cd}$ and demonstrated a unique seasonal pattern with highest concentration during monsoon season and lowest during pre monsoon season (Fig. 2-5).

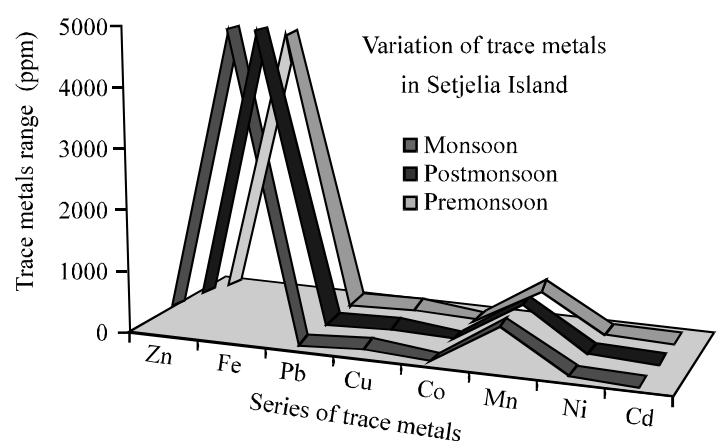

Fig. 2: Variation of dissolved trace metals in St-1

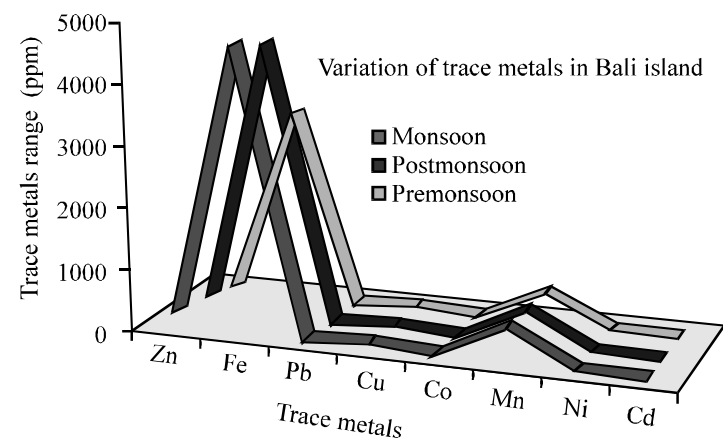

Fig. 3: Variation of dissolved trace metals in St-2

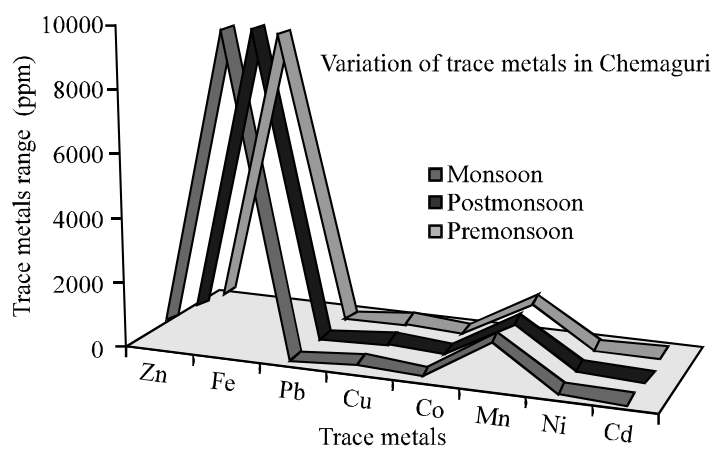

Fig. 4: Variation of dissolved trace metals in St-3

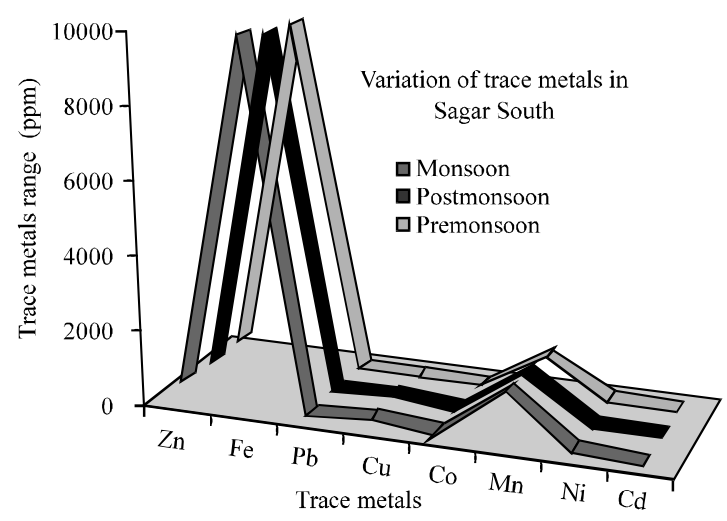

Fig. 5: Variation of dissolved trace metals in St-4 


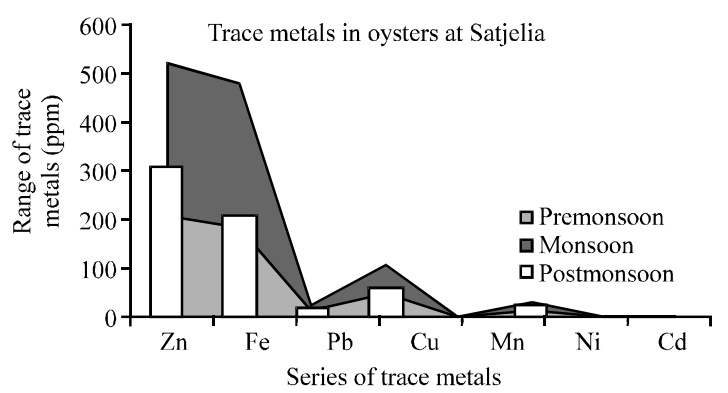

Fig. 6: Variation of trace metals in Saccostrea cucullata at St-1

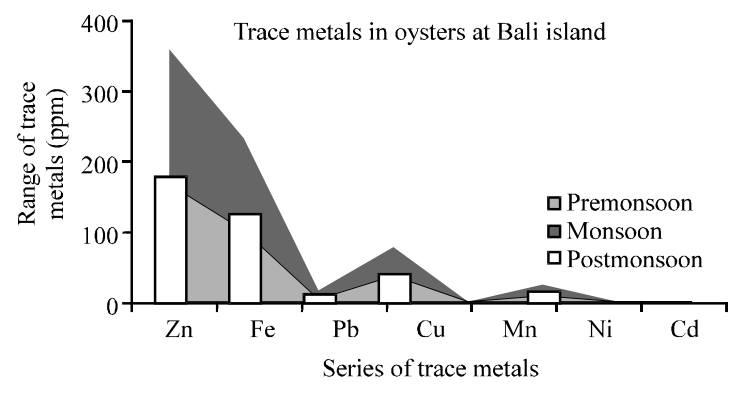

Fig. 7: Variation of trace metals in Saccostrea cucullata at St-2

Significant spatial variations of heavy metal concentrations in estuarine system of Indian Sundarban were observed between the selected stations which reflects the adverse impact of industrialization and urbanization on the coastal waters and found in the order, Sagar South $>$ Chemaguri $>$ Satjelia $>$ Bali island. In the present study, trace metal concentration in Saccostrea cucullata followed the order $\mathrm{Zn}>\mathrm{Fe}>\mathrm{Cu}>\mathrm{Mn}>\mathrm{Pb}>\mathrm{Co}>$ $\mathrm{Ni}>\mathrm{Cd}$.

Significant seasonal variation of trace metal accumulation (ppm) for Saccostrea cucullata observed that exhibited a unique seasonal pattern with highest values during the monsoon season. Moreover, the trace metal concentrations at four stations observed in the order Sagar South $>$ Chemaguri $>$ Satjelia $>$ Bali island (Fig. 6-9).

Two-way Analysis of Variance (ANOVA) was used to assess the heavy metals concentration variation according to location and water and Saccostrea cucullata. Table 5 shows the Two-way ANOVA result of this study. In the present study, all the trace metal accumulation pattern between water and Saccostrea cucullata were completely differences $(\mathrm{p}<0.05)$ because all the cases it was found that $\mathrm{F}_{\text {obs }} \mathrm{F}_{\text {crit }}$ The significant negative correlations $(\mathrm{p}<0.05)$ of trace metal accumulation between ambient water body and Saccostrea cucullata were observed in all the stations ( Table 6-9).

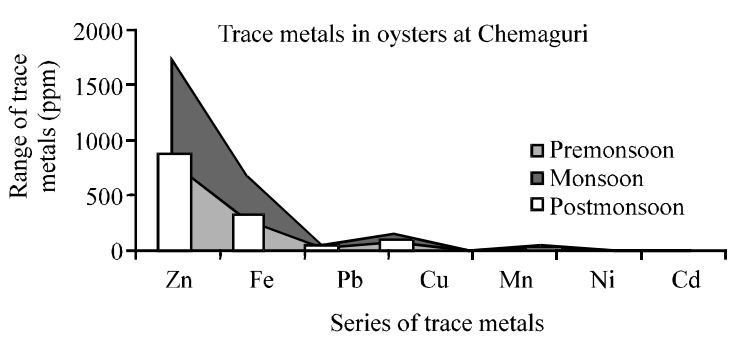

Fig. 8: Variation of trace metals in Saccostrea cucullata at St-3

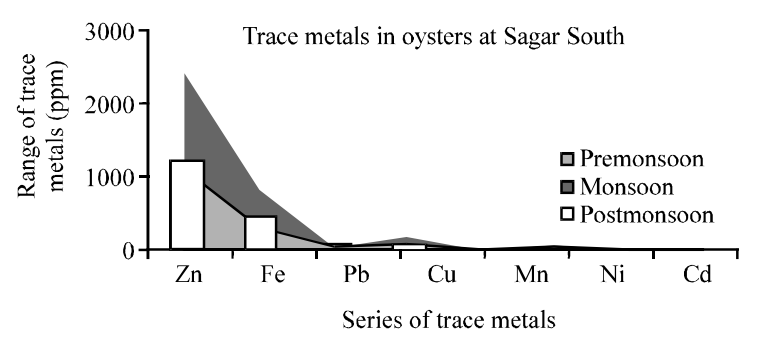

Fig. 9: Variation of trace metals in Saccostrea cucullata at St-4

The Hooghly estuary, situated on the western sector of the Indian Sundarban receives drainage from these adjacent cities which have sewage outlets into the estuarine system. The chain of factories and industries situated on the western bank of the Hooghly estuary is a major cause behind the gradual transformation of this beautiful ecotone into stinking cesspools of the megapolis (Mitra and Choudhury, 1992).

This estuarine complex is considered possibly the most polluted estuary in the world with almost a large number of main factories located close to the mouth discharging almost half a billion liters a day of untreated waste including the effluent from pulp and paper mills, pesticides manufacturing plants, distilleries, thermal power plants, yeast, rayon, cotton, vegetable oils, soap, fertilizers, leather manufacturing units and antibiotic plants.

About 1125 million liters of waste water is discharged per day through Hooghly estuary. A vital ingredient of the released wastes is the heavy metal (UNEP, 1992). In the present study all the trace metals concentration in water and Saccostrea cucullata were observed highest concentration at Sagar South and lowest recorded at Bali island. Continuous receiving industrial drainage of Kolkata, Howrah and Haldia port through Hooghly-Matla estuarine complex lead to such high level of trace metals in western sector of Indian Sundarban (Mitra et al., 2010).

The present study exhibited significant spatial variation in metal level in Saccostrea cucullata between the western and central sectors of Indian Sundarbans 
Environ. Res. J., 5 (3): 121-130, 2011

Table 5: Two-way ANOVA analysis of heavy metals in water and Saccostrea cucullota

\begin{tabular}{lllrlrll}
\hline Metals & Variation & Sum of square & $\mathrm{df}$ & Mean square & \multicolumn{1}{c}{ F-ratio } & $\mathrm{p}$-value & $\mathrm{F}_{\text {crit }}$ \\
\hline $\mathrm{Fe}$ & Seasonal difference & 38885822 & 11 & 3535074.8 & 1.194189 & 0.386862 & 2.817930 \\
& Events differences & 248162129 & 1 & 248162129 & 83.832010 & 1.77 & 4.844336 \\
$\mathrm{Zn}$ & Seasonal difference & 1525127 & 11 & 138647.9 & 2.037728 & 0.126646 & 2.817930 \\
& Events differences & 509521.6 & 1 & 509521.6 & 7.488512 & 0.019252 & 4.844336 \\
$\mathrm{Cu}$ & Seasonal difference & 18847.96 & 11 & 1713.451 & 22.176400 & 6.33 & 2.817930 \\
& Events differences & 5323.175 & 1 & 5323.175 & 68.895380 & 4.59 & 4.844336 \\
$\mathrm{~Pb}$ & Seasonal variation & 2808.024 & 11 & 255.2749 & 15.065340 & 0.000044 & 2.817930 \\
& Events differences & 316.6814 & 1 & 316.6814 & 18.689310 & 0.001208 & 4.844336 \\
$\mathrm{Mn}$ & Seasonal variation & 631176 & 11 & 57379.63 & 1.143295 & 0.4141 & 2.817930 \\
& Events differences & 4530514 & 1 & 4530514 & 90.270960 & 1.23 & 4.844336 \\
$\mathrm{Ni}$ & Seasonal variation & 1953.413 & 11 & 177.583 & 1.152854 & 0.4088 & 2.817930 \\
& Events differences & 6774.096 & 1 & 6774.096 & 43.976880 & 0.000037 & 4.844336 \\
$\mathrm{Cd}$ & Seasonal difference & 25.65565 & 11 & 2.332331 & 1.411113 & 0.288786 & 2.817930 \\
& Events differences & 27.4562 & 1 & 27.4562 & 16.611620 & 0.001833 & 4.844336 \\
$\mathrm{Co}$ & Seasonal difference & 231.3653 & 11 & 21.03321 & 2.839699 & 0.048802 & 2.817930 \\
& Events differences & 384 & 1 & 384 & 51.843930 & 0.0000175 & 4.844336 \\
& & & & & &
\end{tabular}

Table 6: Inter-relationship of heavy metals accumulation between water and Saccostrea cucullata in the Station-1

\begin{tabular}{|c|c|c|c|c|c|c|c|c|c|c|c|c|c|c|c|c|}
\hline & Wzn & $\mathrm{OZn}$ & Wfe & Ofe & WPb & Opb & $\mathrm{WCu}$ & $\mathrm{OCu}$ & WCo & $\mathrm{OCO}$ & WMn & $\mathrm{OMn}$ & WNi & $\mathrm{ONi}$ & WCd & $\mathrm{OCd}$ \\
\hline Wzn & 1 & & & & & & & & & & & & & & & \\
\hline $\mathrm{OZn}$ & 0.887744 & 1 & & & & & & & & & & & & & & \\
\hline WFe & 0.978006 & 0.772203 & 1 & & & & & & & & & & & & & \\
\hline $\mathrm{OFe}$ & 0.305112 & 0.709249 & 0.099771 & 1 & & & & & & & & & & & & \\
\hline $\mathrm{WPb}$ & 0.740095 & 0.966593 & 0.58355 & 0.866247 & 1 & & & & & & & & & & & \\
\hline $\mathrm{OPb}$ & 0.6734 & 0.938125 & 0.504394 & 0.909489 & 0.995546 & 1 & & & & & & & & & & \\
\hline WCu & 0.928239 & 0.6528 & 0.98541 & -0.07103 & 0.436825 & 0.350077 & 1 & & & & & & & & & \\
\hline $\mathrm{OCu}$ & 0.538707 & 0.866065 & 0.351135 & 0.966686 & 0.965273 & 0.985602 & 0.186654 & 1 & & & & & & & & \\
\hline WCo & 0.501175 & 0.843267 & 0.309662 & 0.976998 & 0.952864 & 0.977223 & 0.143316 & 0.999035 & 1 & & & & & & & \\
\hline $\mathrm{OCO}$ & 0.776327 & 0.399015 & 0.890725 & -0.36341 & 0.150658 & 0.05679 & 0.95509 & -0.11284 & -0.15638 & 1 & & & & & & \\
\hline WMn & 0.999349 & 0.903778 & 0.969842 & 0.33928 & 0.763882 & 0.699641 & 0.91421 & 0.568759 & 0.532077 & 0.753074 & 1 & & & & & \\
\hline $\mathrm{OMn}$ & 0.98976 & 0.812943 & 0.997764 & 0.166052 & 0.636522 & 0.560978 & 0.971832 & 0.412931 & 0.372522 & 0.858352 & 0.983964 & 1 & & & & \\
\hline WNi & 0.456175 & 0.814617 & 0.260532 & 0.986641 & 0.936066 & 0.965065 & 0.092414 & 0.995471 & 0.998686 & -0.20678 & 0.487992 & 0.324479 & 1 & & & \\
\hline $\mathrm{ONi}$ & 0 & 0 & 0 & 0 & 0 & 0 & 0 & 0 & 0 & 0 & 0 & 0 & 0 & 1 & & \\
\hline WCd & 0.77632 & 0.39901 & 0.89072 & -0.3634 & 0.15065 & 0.05679 & 0.95509 & -0.1128 & -0.1563 & 1 & 0.75307 & 0.8583 & -0.206 & 0 & 1 & \\
\hline $\mathrm{OCd}$ & 0 & 0 & 0 & 0 & 0 & 0 & 0 & 0 & 0 & 0 & 0 & 0 & 0 & 0 & 0 & 1 \\
\hline
\end{tabular}

$\mathrm{W}=$ Water body, $\mathrm{O}=$ Oyster accumulation of trace metals

Table 7: Inter-rel ationship of heavy metals accumulation between water and oyster in the Station-2

\begin{tabular}{|c|c|c|c|c|c|c|c|c|c|c|c|c|c|c|c|c|}
\hline & Wzn & $\mathrm{OZn}$ & $\mathrm{WFe}$ & $\mathrm{OFe}$ & $\mathrm{WPb}$ & $\mathrm{OPb}$ & $\mathrm{WCu}$ & $\mathrm{OCu}$ & WCo & $\mathrm{OCo}$ & WMn & $\mathrm{OMn}$ & WNi & $\mathrm{ONi}$ & $\mathrm{WCd}$ & $\mathrm{OCd}$ \\
\hline Wzn & 1 & & & & & & & & & & & & & & & \\
\hline OZn & 0.25694 & 1 & & & & & & & & & & & & & & \\
\hline WFe & 0.57324 & 0.93916 & 1 & & & & & & & & & & & & & \\
\hline $\mathrm{OFe}$ & 0.59279 & 0.93062 & 0.99971 & 1 & & & & & & & & & & & & \\
\hline WPb & 0.14860 & 0.99388 & 0.89547 & 0.88450 & 1 & & & & & & & & & & & \\
\hline $\mathrm{OPb}$ & 0.66668 & 0.891617 & 0.99289 & 0.99547 & 0.83614 & 1 & & & & & & & & & & \\
\hline WCu & 0.31983 & 0.99784 & 0.95968 & 0.95264 & 0.98448 & 0.91941 & 1 & & & & & & & & & \\
\hline $\mathrm{OCu}$ & 0.31086 & 0.99841 & 0.95698 & 0.94972 & 0.98609 & 0.91566 & 0.99995 & 1 & & & & & & & & \\
\hline WCo & 0.6779 & 0.88465 & 0.99097 & 0.99391 & 0.82773 & 0.99988 & 0.91335 & 0.90946 & 1 & & & & & & & \\
\hline OCo & -0.0541 & 0.95109 & 0.78713 & 0.77206 & 0.97939 & 0.70814 & 0.92876 & 0.93222 & 0.69735 & 1 & & & & & & \\
\hline WMn & 0.30056 & 0.99896 & 0.95379 & 0.94628 & 0.98783 & 0.91126 & 0.99979 & 0.99994 & 0.90491 & 0.93608 & 1 & & & & & \\
\hline OMn & 0.25800 & 0.99999 & 0.93954 & 0.93103 & 0.99375 & 0.89211 & 0.99791 & 0.99848 & 0.88516 & 0.95075 & 0.99901 & 1 & & & & \\
\hline $\mathrm{WNi}$ & 0.60085 & 0.92690 & 0.99941 & 0.99995 & 0.87977 & 0.99637 & 0.94954 & 0.94653 & 0.99497 & 0.76563 & 0.94299 & 0.92731 & 1 & & & \\
\hline ONi & 0 & 0 & 0 & 0 & 0 & 0 & 0 & 0 & 0 & 0 & 0 & 0 & 0 & 1 & & \\
\hline WCd & -0.0541 & 0.95109 & 0.78713 & 0.77206 & 0.97939 & 0.70814 & 0.92876 & 0.93222 & 0.69735 & 1 & 0.93608 & 0.95075 & 0.76563 & 0 & 1 & \\
\hline $\mathrm{OCd}$ & 0 & 0 & 0 & 0 & 0 & 0 & 0 & 0 & 0 & 0 & 0 & 0 & 0 & 0 & 0 & 1 \\
\hline
\end{tabular}

$\mathrm{W}=$ Water body, $\mathrm{O}=$ Oyster accumulation of trace metals

which may be due to different salinity profile as well as environmental conditions. The western part of the Gangetic delta is connected to Himalayan glacier through Bhagirathi river. Researchers pointed out that the glaciers in the Himalayan range are melting at the rate of $23 \mathrm{~m} \mathrm{year}^{-1}$ (Hasnain, 2002). This along with Farraka discharge has resulted in gradual freshening of the system which has role in elevation of dissolved metal level in the system by way lowering of $\mathrm{pH}$. The presence of chain of factories and industries along the bank of Hooghly estuary is another major cause of increased metal level in the aquatic phase of Hooghly estuary that have been reflected in the oyster muscles. The central sector on contrary is deprived from freshwater supply of Ganga-Bhagirathi system on account of siltation of Bidyadhari river in the 15th century. The Matla river, in the central sector is now tide fed with an increasing trend of salinity (Mitra et al., 2009). In the present study trace 
Environ.Res. J., 5 (3): 121-130, 2011

\begin{tabular}{|c|c|c|c|c|c|c|c|c|c|c|c|c|c|c|c|c|}
\hline & Wzn & $\mathrm{OZn}$ & $\mathrm{WFe}$ & $\mathrm{OFe}$ & $\mathrm{WPb}$ & $\mathrm{OPb}$ & $\mathrm{WCu}$ & $\mathrm{OCu}$ & WCo & $\mathrm{OCo}$ & WMn & $\mathrm{OMn}$ & $\mathrm{WNi}$ & ONi & $\mathrm{WCd}$ & $\mathrm{OCd}$ \\
\hline Wzn & 1 & & & & & & & & & & & & & & & \\
\hline OZn & 0.95541 & 1 & & & & & & & & & & & & & & \\
\hline WFe & -0.9322 & -0.7838 & 1 & & & & & & & & & & & & & \\
\hline $\mathrm{OFe}$ & 0.86678 & 0.97538 & -0.6276 & 1 & & & & & & & & & & & & \\
\hline $\mathrm{WPb}$ & 0.94262 & 0.99917 & -0.7579 & 0.98353 & 1 & & & & & & & & & & & \\
\hline $\mathrm{OPb}$ & 0.80071 & 0.94189 & -0.5296 & 0.99278 & 0.95476 & 1 & & & & & & & & & & \\
\hline $\mathrm{WCu}$ & 0.91461 & 0.99322 & -0.7063 & 0.99440 & 0.99712 & 0.97455 & & & & & & & & & & \\
\hline $\mathrm{OCu}$ & 0.91916 & 0.99448 & -0.7143 & 0.99313 & 0.99792 & 0.97193 & 0.99993 & 1 & & & & & & & & \\
\hline WCo & 0.96892 & 0.99876 & -0.8137 & 0.96319 & 0.99591 & 0.92401 & 0.98620 & 0.98802 & 1 & & & & & & & \\
\hline $\mathrm{OCo}$ & 0.89859 & 0.98808 & -0.6789 & 0.9977 & 0.99352 & 0.98236 & 0.99927 & 0.99878 & 0.97920 & 1 & & & & & & \\
\hline WMn & 0.88224 & 0.98191 & -0.6521 & 0.99949 & 0.98879 & 0.98845 & 0.99726 & 0.99636 & 0.97128 & 0.99935 & 1 & & & & & \\
\hline OMn & 0.99143 & 0.98579 & -0.8769 & 0.92449 & 0.97815 & 0.87210 & 0.95959 & 0.96273 & 0.99293 & 0.94820 & 0.93617 & 1 & & & & \\
\hline WNi & 0.95152 & 0.99991 & -0.7757 & 0.97814 & 0.99961 & 0.94615 & 0.99463 & 0.99575 & 0.99803 & 0.98999 & 0.98428 & 0.98354 & 1 & & & \\
\hline $\mathrm{ONi}$ & 0.69553 & 0.87667 & -0.3884 & 0.96118 & 0.89549 & 0.98733 & 0.92665 & 0.92230 & 0.85164 & 0.94026 & 0.95189 & 0.78342 & 0.88281 & 1 & & \\
\hline WCd & 0.95975 & 0.99988 & -0.7931 & 0.97194 & 0.99844 & 0.93672 & 0.99135 & 0.99278 & 0.99939 & 0.98565 & 0.97895 & 0.98821 & 0.99960 & 0.86932 & 1 & \\
\hline $\mathrm{OCd}$ & 0 & 0 & 0 & 0 & 0 & 0 & 0 & 0 & 0 & 0 & 0 & 0 & 0 & 0 & 0 & 1 \\
\hline
\end{tabular}

$\mathrm{W}=$ Water body, $\mathrm{O}=$ Oyster accumulation of trace metals

Table 9: Inter-relationship of heavy metals accumulation between water and oyster in the Station-4

\begin{tabular}{|c|c|c|c|c|c|c|c|c|c|c|c|c|c|c|c|c|}
\hline & WZn & $\mathrm{OZn}$ & WFe & $\mathrm{OFe}$ & $\mathrm{WPb}$ & $\mathrm{OPb}$ & $\mathrm{WCu}$ & $\mathrm{OCu}$ & WCo & $\mathrm{OCo}$ & WMn & OMn & $\mathrm{WNi}$ & ONi & WCd & OCd \\
\hline WZn & 1 & & & & & & & & & & & & & & & \\
\hline $\mathrm{OZn}$ & 0.95389 & 1 & & & & & & & & & & & & & & \\
\hline WFe & 0.99540 & 0.97824 & 1 & & & & & & & & & & & & & \\
\hline $\mathrm{OFe}$ & 0.90845 & 0.99202 & 0.94429 & 1 & & & & & & & & & & & & \\
\hline WPb & 0.86615 & 0.97622 & 0.91002 & 0.99576 & 1 & & & & & & & & & & & \\
\hline $\mathrm{OPb}$ & 0.99067 & 0.98589 & 0.99916 & 0.95693 & 0.92617 & 1 & & & & & & & & & & \\
\hline $\mathrm{WCu}$ & 0.90700 & 0.99158 & 0.94315 & 0.99999 & 0.99607 & 0.95592 & 1 & & & & & & & & & \\
\hline $\mathrm{OCu}$ & 0.95560 & 0.99998 & 0.97942 & 0.99128 & 0.97496 & 0.98684 & 0.99082 & 1 & & & & & & & & \\
\hline WCo & 0.79305 & 0.93932 & 0.84772 & 0.97506 & 0.99134 & 0.86865 & 0.97582 & 0.93733 & 1 & & & & & & & \\
\hline $\mathrm{OCo}$ & 0.29566 & 0.56876 & 0.38576 & 0.66789 & 0.73352 & 0.42307 & 0.67046 & 0.56402 & 0.81639 & 1 & & & & & & \\
\hline WMn & 0.92775 & 0.99699 & 0.95922 & 0.99881 & 0.99009 & 0.96995 & 0.99863 & 0.99652 & 0.96308 & 0.63080 & 1 & & & & & \\
\hline OMn & 0.98207 & 0.99337 & 0.99560 & 0.97095 & 0.94483 & 0.99859 & 0.97012 & 0.99401 & 0.89365 & 0.47043 & 0.98146 & 1 & & & & \\
\hline WNi & 0.0208 & 0.31996 & 0.11645 & 0.43682 & 0.51771 & 0.15687 & 0.43992 & 0.31450 & 0.62554 & 0.96124 & 0.39244 & 0.20891 & 1 & & & \\
\hline ONi & 0.99895 & 0.93919 & 0.98999 & 0.88842 & 0.84243 & 0.98342 & 0.88683 & 0.94115 & 0.76441 & 0.25174 & 0.90975 & 0.97244 & -0.0248 & 1 & & \\
\hline WCd & 0.73398 & 0.90399 & 0.79563 & 0.95067 & 0.97517 & 0.81968 & 0.95173 & 0.90151 & 0.99580 & 0.86581 & 0.93441 & 0.84884 & 0.69431 & 0.70221 & 1 & \\
\hline $\mathrm{OCd}$ & 0.99894 & 0.93919 & 0.98999 & 0.88842 & 0.84243 & 0.98342 & 0.88683 & 0.94115 & 0.76441 & 0.25174 & 0.90975 & 0.97244 & -0.024 & 1 & 0.70221 & 1 \\
\hline
\end{tabular}

$\mathrm{W}=$ Water body, $\mathrm{O}=$ Oyster accumulation of trace metals

metal accumulation in Saccostrea cucullata exhibited a unique seasonal pattern with highest values during the monsoon season and lowest during pre-monsoon season. This variation may be attributed to huge run-off from the adjacent land masses during the monsoon. During monsoon, the dilution factor (df) of all the sampling stations in the coastal and estuarine zone of West Bengal increase manifold which results in the decrease of salinity and $\mathrm{pH}$. The lowering of $\mathrm{pH}$ might facilitate the dissolution of the precipitated form of metals and increase the amount of metallic ions in solutions (Mitra, 1998; Bansal, 1998).

In the present study, $\mathrm{Pb}$ concentration level (17 ppm) in Saccostrea cucullata was significantly different with respect to the other trace metals. Present study indicated the concentration of $\mathrm{Pb}$ found higher range (5.10-30.60 ppm) than recommended value for $\mathrm{FAO} / \mathrm{WHO}$ (1992) as $0.05 \mathrm{ppm}$, US-FDA (2003) as $1.7 \mathrm{ppm}$ for sea food. Mtanga and Machiwa (2007) stated that high level of $\mathrm{Pb}$ in Saccostrea cucullata found indicative of the contributions of heavy metal pollution from several anthropogenic sources such as industrial and agricultural activities. Central Sundarbans exposed to all these activities being proximal to the highly urbanized city of Kolkata, Howrah and the newly emerging Haldia port-cum-industrial complex. On the other hand, western Sundarbans fall in the navigational route of the ships and tankers for Haldia port. This Hooghly channel is also the recipient for the wastes of the upstream region that finds its way to the Bay of Bengal. Oysters normally accumulate high concentrations of $\mathrm{Cu}$ and $\mathrm{Zn}$ (Engel and Brouwer, 1982) and considered strong net accumulators of both metals (Rainbow et al., 1990). Present study showed that the average range of $\mathrm{Zn}$ level in Saccostrea cucullata was $626 \mathrm{ppm}$ which is higher range $100 \mathrm{ppm}$ by World Health Organization (WHO, 1989) but lower than Food and Agricultural Organization (FAO/WHO, 1992) level as $1000 \mathrm{ppm}$ for $\mathrm{Zn}$ in sea food. Present study showed that Saccostrea cucullata at Sagar South accumulated high range of $\mathrm{Zn}$ level (1096.45-1321.50 ppm) for all the year round. Largest delta of Indian Sundarbans and large number of fishing vessels and trawlers in adjacent island to the fishing harbours may be one possible source of contamination of this metal through antifouling paints. 
Present study indicated that Saccostrea cucullata is at high risk of $\mathrm{Cu}$ pollution in the western Sundarbans. WHO (1989) and FAO/WHO (1992) proposed the standardization of $\mathrm{Cu}$ range of marine sea food 30 and $10 \mathrm{ppm}$, respectively but the range of this metal in Saccostrae cucullata (34.80-116 ppm) indicated far away from certified value. Genrally, Ship bottom paints has been found to produce very high concentration of $\mathrm{Cu}$ in seawater and sediments in harbours of Great Britain and southern California (Bellinger and Benham, 1978). From the different investigation, it was found that western sundarbans exhibited maximum $\mathrm{Cu}$ concentrations in the surface water and aquatic living organisms which can't only be attributed to the conditioning of huge number of authorized and unauthorized fishing vessels, trawlers, traveler boat and cargo ships in the creeks and bay regions but also to the leaching from several aquacultural farms in the area that use $\mathrm{Cu}$ compounds as algicide (Mitra, 1998).

From the ANOVA analysis, significant seasonal differences $(p<0.05)$ have been found between water and Saccostrea cucullata for the accumulation of $\mathrm{Cu}$ and $\mathrm{Pb}$ because of run off process the load of heavy metal changes with season. According to Hashmi et al. (2002) continental sources (river runoff and atmospheric transport), oceanic sources (upwelling) and digenetic exchanges at water-sediment interface have been identified as the factors that influence the heavy metals in coastal aquaculture organisms. Moreover, anthropogenic atmospheric inputs, sewage sludge and fertilizers are often inferred to be significant because of important these metals input. The relationships evaluated between metal concentration and season and location sites suggest an influence of age and physiological patterns of oysters in metal uptake. This fact may condition the interpretation of the experimental data and multivariate analysis was found as an important tool to interpret the analytical data obtained. In that sense, ANOVA and correlation analysis confirmed that trace metals patterns vary throughout the sampling area and reflect contaminant source locations.

Regarding the economic significance of this bivalve mollusk, favourable natural farming conditions and planned production increase, more detailed knowledge of the spatiotemporal distribution of this element would allow the appropriate planning of production locations and sale of the final product in the market. In addition, increased metal concentrations can be expected owing to the global warming effect (Sokolova, 2004) and the planning of prevention measures, e.g. use of triploids for their faster growth (Amiard et al., 2005), demands more detailed knowledge and awareness of the current state.

\section{CONCLUSION}

The knowledge of heavy metal concentrations in native species is very important with respect to nature management, human consumption of these species and to determine the most useful biomonitor species and the most polluted area. The River Ganga in the Indian sub-continent is the lifeline of millions in terms of livelihood and natural resources.

However, due to rapid industrialization, urbanization and unplanned tourism, a negative impact has been exerted on the positive health of the aquatic system. The contamination of water is also transmitted in the biological compartment, many of which are consumed as food by the local people. The present study is important not only from the human health point of view but it also presents a comparative account of heavy metals in water and oyster Saccostrea cucullata from western and central two sectors of Gangetic delta that are physico-chemically different.

The present zone of investigation situated in and around Indian Sundarbans, a world Heritage site, demands regular monitoring of metal status for effective management and conservation of this famous mangrove gene pool. Industrial discharge and heavy use of agriculture contaminants such as fertilizers and pesticides should be controlled as a remedy to minimize coastal pollution in Indian Sundarbans. The high concentrations of heavy metals in Saccostrea cucullata from Western Sundarbans is a cause of concern and requires regular monitoring of water quality around the point sources present opposite to the western bank of the island.

\section{ACKNOWLEDGEMENTS}

Researchers are grateful to Department of Forest, Govt. of West Bengal for helping us collect the shrimp samples from central sector of Indian Sundarbans. The financial support provided by West Bengal State Compensatory Afforestation Management Planning Authority (CAMPA) is gratefully acknowledged.

\section{REFERENCES}

Amiard, J.C., H. Perrein-Ettajani, A. Gerard, J.P. Baud and C. Amiard-Triquet, 2005. Influence of ploidy and metal-metal interactions on the accumulation of $\mathrm{Ag}, \mathrm{Cd}$ and $\mathrm{Cu}$ in oysters Crassostrea gigas thunberg. Arch. Environ. Contamination Toxicol., 48: $68-74$. 
Bansal, O.P., 1998. Heavy metal pollution of soil and ponds due to sewage irrigation. Indian J. Environ. Health, 40: 51-57.

Bellinger, E.G. and B.R. Benham, 1978. The levels of metals in dock-yard sediments with particular reference to the contributions from ship-bottom paints. Environ. Pollut., 15: 71-81.

Chaudhuri, A.B. and A. Choudhury, 1992. Mangroves of the Sundarban. Vol. 1, IUCN, Dhaka, pp: 250 .

Date, A.R. and A.L. Gray, 1988. Applications of Inductively Coupled Plasma Source Mass Spectrometry. Blackie Publishers, Glassgow.

Engel, D.W. and M. Brouwer, 1982. Detoxification of Accumulated Trace Metals by the American Oyster, Crassostrea virginica: Laboratory vs. Environment. In: Physiological Mechanisms of Marine Pollutant Toxicity, Vernberg, W.B. (Ed.). Academic Press, New York, pp: 89-107.

FAO, 2002. FAO Aquaculture Production: 1950-2002: FAO Yearbook Fishery Statistics. Vol. 94, Food Agriculture Organization, New York.

FAO/WHO, 1992. FAO/WHO, Food Standard Programme. 2nd Edn., Vol. 1, Codex Alimentarius Commission, Geneva.

Goldberg, E.D., V.T. Bowen, J.W. Farrington, G.R. Harvey and J.H. Martin et al., 1978. The mussel watch. Environ. Conserv., 5: 101-125.

Hashmi, M.I., S. Mustafa and S.A. Tariq, 2002. Heavy metal concentrations in water and tiger prawn (Penaeus monodon) from grow-out farms in Sabah, North Borneo. Food Chem., 79: 151-156.

Hasnain, S.I., 2002. Himalayan Glaciers Meltdown: Impact on South Asian Rivers. In: FRIEND 2002-Regional Hydrology: Bridging the Gap Between Research and Practice, Van Lanen, H.A.J. and S. Demuth (Eds.). IAHS Publication 274, International Association of Hydrological Sciences, Wallingford, UK., ISBN: 1-901502-81-3, pp: 417-423.

Jacqueline, W., J.L. Ruesink and A.C. Trimble, 2009. The nearly forgotten oyster: Ostrea lurida Carpenter 1864 (Olympia Oyster) history and management in Washington State. J. Shellfish Res., 28: 43-49.

Jaffe, R., I. Leal, J. Alvarado, P.R. Gardinali and J.L. Sericano, 1999. Baseline study on the levels of organic pollutants and heavy metals in bivalves from the Morrocoy National park, Venezuela. Mar. Pollut. Bull., 36: 925-929.
Lacerda, L.D., W.C. Pfeiffer and M. Fiszman, 1985. Intertidal beach sands as monitor for heavy metal pollution in coastal water bodies. Environ. Technol. Lett., 6: 123-128.

Mitra, A. and A. Choudhury, 1992. Trace metals in macrobenthic molluscs of the Hooghly estuary, India. Mar. Pollut. Bull., 26: 521-522.

Mitra, A., 1998. Status of coastal pollution in West Bengal with special reference to heavy metals, India. J. Indian Ocean Stud., 5: $135-138$.

Mitra, A., 2000. The Northwestern Bay of Bengal and Deltaic Sundarbans. In: Seas at the Millennium: An Environmental Evaluation, Sheppard, C. (Ed.). Elsevier Science, London, pp: 143-157.

Mitra, A., K. Banerjee, G. Rajrupa and S.K. Ray, 2010. Bioaccumulation pattern of heavy metals in the shrimps of the lower stretch of the River Ganga. Mesopot. J. Mar. Sci., 25: 1-14.

Mitra, A., K. Banerjee, K. Sengupta and A. Gangopadhyay, 2009. Pulse of climate change in Indian Sundarbans: A myth or reality. Natl. Acad. Sci. Lett., 32: 19-25.

Mitra, A., S. Trivedi and A. Coudhury, 1995. Inter-relationship between gross primary production and metal accumulation by Crassostrea cucullata in the Hooghly estuary. Poll. Res. Maharastra, 13: $391-394$.

Mtanga, A. and J.F. Machiwa, 2007. Heavy metal pollution levels in water and oysters, Saccostrea cucullata, from Mzinga Creek and Ras Dege mangrove ecosystems, Tanzania. Afri. J. Aquatic Sci., 32: $235-244$.

UNEP, 1992. Pollution and the marine environment in the Indian Ocean. UNEP Regional Seas Report and Studies, pp: 13.

Nadkarni, R.A., 1984. Applications of microwave oven sample dissolution in analysis. Anal. Chem., 56: 2233-2237.

Rainbow, P.S., D.J.H. Phillips and M.H. Depledge, 1990. The significance of trace metal concentrations in marine invertebrates a need for laboratory investigation of accumulation strategies. Mar. Pollut. Bull., 21: 321-324.

Raposo, J.C., L. Bartolome, E. Cortazar, G. Arana and M. Zabaljauregui et al., 2009. Trace metals in oysters, Crassotrea sps., from UNESCO protected natural reserve of urdaibai: Space-time observations and source identification. Bull. Environ. Contam Toxicol., 83: $223-229$. 
Sokolova, I.M., 2004. Cadmium effects on mitochondrial function are enhanced by elevated temperatures in a marine poikilotherm, Crassostrea virginica Gmelin (Bivalvia: Ostreidae). J. Exp. Biol., 207: 2639-2648.

Srinivasa, R., M. Bhavesh, D. Sunil, J. Manish and $\mathrm{K}$. Leena et al., 2007. Bioaccumulation of heavy metals in some commercial fishes and crabs of gulf of cambay, India. Curr. Sci., 92: 1489-1491.

Takeoka, H., A. Ramesh, H. Iwata, S. Tanabe and A.N. Subramanian et al., 1991. Fate of the insecticide $\mathrm{HCH}$ in the tropical coastal area of South India. Mar. Pollut. Bull., 22: 290-297.
Turkmen, A., M. Turkmen and Y. Tepe, 2005. Biomonitoring of heavy metals from Iskenderun Bay using two bivalve species Chama pacifica Broderip, 1834 and Ostre a stentina Payraudeau, 1826. Turk. J. Fish. Aquatic Sci., 5: 107-111.

US-FDA, 2003. Guide for the Control of Molluscan Shellfish. Public Health Service, Food and Drug Administration, USA., pp: 120.

WHO, 1989. Heavy metals environmental aspects. Environmental Health Criteria, No. 85. Geneva, Switzerland. 